\title{
Fundamental principles of the cultural-activity approach in the psychology of giftedness
}

\author{
Julia D. Babaeva \\ Lomonosov Moscow State University, Moscow, Russia
}

\begin{abstract}
This article examines the cultural-activity approach to the study of giftedness, which is based on the ideas of L. S. Vygotsky, A. N. Leontiev, and O. K. Tikhomirov. Three basic principles of this approach are described: the principle of polymorphism, the dynamic principle, and the principle of the holistic analysis of the giftedness phenomenon. The article introduces the results of empirical research (including a 10-year longitudinal study), which verifies the efficacy of the cultural-activity approach and its prospects for solving actual problems in the psychology of giftedness in light of the creation of new diagnostic procedures and methods of education and the development of gifted children.
\end{abstract}

Keywords: giftedness, creativity, intelligence, dynamic theory of giftedness, culturalactivity approach, psychodiagnostic training, types of giftedness

Attention to the problems of giftedness is determined largely by public interest connected to the provision of progress in different spheres of human activity. Gifted people are seen not only as a source of national pride but also as a "strategic resource" because of their achievements. For this reason, in many countries including Russia the programs for gifted children and youth are carried out by the government, and the relevant diagnostic, educational, and developmental issues are elaborated. Special attention is given to providing gifted people with help and support, specifically psychological.

There are more than 100 definitions of "giftedness" in contemporary psychology as well as dozens of theories, many of which turn out to be "local" and application-specific (Freeman, 1995; Babaeva, 2008; Babaeva \& Voiskounsky, 2003). Such abundance complicates rather than simplifies giftedness identification and exploration of its patterns and of the psychological mechanisms of its genesis and development. The lack of general methodological publications results in empirical research and applied work that is ineffective; they do not have a strong methodological foundation.

In my view the cultural-activity approach, which is attracting rising interest, can be such a foundation. The methodological potential of classic works by L. S. Vygotsky, A. N. Leontiev, S. L. Rubinstein, and A. R. Luria has not yet been fully ex- 
plored. These works are now being successfully revealed in contemporary studies that are carried out using new psychological techniques and modern methods of data analysis.

The aim of this article is the substantiation of the possibility of using this approach, which is based on Vygotsky's ideas, Leontiev's activity theory, and the theoretical-experimental concepts developed in O. K. Tikhomirov's scientific school, as a strong foundation for solving the many problems that the modern psychology of giftedness faces. Among the essentials of this approach are the principles of polymorphism and of dynamics, together with the holistic analysis of the phenomenon of giftedness (Babaeva, 2008).

\section{The principle of polymorphism}

The principle of polymorphism underlines the qualitative diversity of different types of giftedness. It refers also to the impossibility of reducing this complex and multiaspect phenomenon to a single item, as is suggested by proponents of the single-factor model of giftedness, which obtained wide acceptance in the past. This model is based on the hypothesis of a G-factor that does not vary according to the type of task and that determines the success of intellectual activity. In this way giftedness was identified with intelligence, particularly with the quantity index of its development, the intelligence quotient (IQ), which is measured by psychometric tests. The popularity of this model can be explained by the relative simplicity of its application and its unambiguous identification of giftedness. Vygotsky (1983) criticized this approach, noting the unacceptable simplification of the giftedness phenomenon. According to critics, abandoning the G-factor idea and accepting the qualitative diversity of different types of giftedness will facilitate radical changes in understanding its nature.

Critics of the single-factor model and the uncritical devotion to tests noted that using this model for the identification of giftedness can lead to gross errors caused by ignorance of the child's potential opportunities, his or her personal traits, and the social environment (Heller, 1997). Students may not achieve their learning potential for various reasons. Their development may be negatively affected by different social-psychological factors; they may, for example, come from dysfunctional families. As a result, the giftedness of many children may be unnoticed, and they get no help and no support. But, despite serious criticism of the single-factor approach, it still quite often forms the theoretical base for many empirical studies and for practical work with gifted children.

Types of giftedness can be distinguished according to different criteria-for example, spheres of activity (musical, linguistic, mathematical). More general abilities can be a criterion as well, as was done in the definition of giftedness suggested by American psychologists and introduced in a report from the Commissioner of Education to the Congress of the United States in 1972. The list of abilities included intellectual abilities, specific academic aptitudes, creative or productive thinking, leadership abilities, abilities in the visual and performing arts, and psychomotor abilities (Marland, 1972).

This classification has been criticized as well. For example, Renzulli pointed out the unacceptable confusion of intellectual, creative, and leadership abilities with 
their realization in the arts or in communication (Renzulli, 1978, 1986; Renzulli, Reis, \& Smith, 1981).

The "operational conception of giftedness" (Bogoyavlenskaya, Shadrikov, Babaeva, Kholodnaya et al., 2003), which was developed by Russian psychologists commissioned by the Ministry of Education, is a new approach to the classification of giftedness. It is based on five main criteria. To describe the qualitative uniqueness of each type of giftedness it is not enough simply to specify its implementation area. It is appropriate to introduce a double criterion-the "kind of activities" and the "sphere of the psyche mediating it." According to this criterion, the main categories of activities are practical, cognitive, artistic-aesthetic, communicative, and spiritual-axiological. These activities, in turn, are provided by three main psychic spheres: intellectual, emotional, and motivational-volitional, each of which is characterized by different levels of psychic organization. For example, with regard to the intellectual sphere, the sensory-motor, spatial-visual, and conceptual-logical levels can be differentiated. Application of this scheme allows the identification and description in detail of types of giftedness with different content; such a description reflects not only the qualitative uniqueness of giftedness but also features specific to a gifted person.

The need to posit creative talent as an independent type of giftedness (as is done in many classifications) is debatable. In everyday representations "smart" and "creative" persons are usually distinguished. The literature presents different perspectives on the relationship of intelligence and creativity: from their independence to their necessary coincidence. According to the theory of the intelligence "threshold," the relationship between indicators of intelligence and creativity is ambiguous and is determined largely by IQ measures (Guilford \& Christensen, 1973; Runco \& Albert, 1986; Sternberg, 1999).

In the operational conception of giftedness a new attempt to resolve these controversial issues is made. Creativity is defined as the development of activity occurring on the initiative of the subject. In the course of this development the continuous improvement and enrichment of the activity itself occurs, new ideas and goals emerge, and the new results are significantly better than those originally expected. The activity the subject is initiating manifests his or her passion for work and desire to continue even after the original goal is reached, at which time new goals are set. In this approach, it is assumed that "creative giftedness" is in fact synonymous with the "giftedness" inherent in any kind of work and is a characteristic of "not just the top-level performance of any activity, but its transformation and development" (Bogoyavlenskaya, Shadrikov, Babaeva, Kholodnaya et al., 2003, p. 22). The value of this approach to teaching practices is also emphasized. It is unacceptable to develop only various educational programs for gifted students (accelerated, advanced, deep). It is necessary also to create an enabling environment to nurture them; such an environment will facilitate the development of intrinsic motivation as well as the formation of a value system as the basis for a person's spirituality.

Other approaches exist. In Tikhomirov's scientific school the analysis of creativity is based on the study of various new formations arising in the subject's activity (Babaeva, Berezanskaya, Vasilyev, Voiskounsky, \& Kornilova, 2009). They may occur in the "pole of the object" (i.e., the object of the activity) and in the "pole of the subject," whose creative process can bring new motives, meanings, emotional 
evaluations, and so forth. Furthermore, in the process of work creative activity is being transformed itself. These changes can be constructive or destructive, as is evidenced by the data obtained in the study of adults' creative crises and of the phenomenon of children's "fear of creativity" (Babaeva, 1998; Babaeva \& Varvaricheva, 2011). The mere existence of these new formations as well as their number does not mean that they are connected to creative giftedness, so deep qualitative analysis is needed. With this approach, the selection of creative giftedness as a special type of giftedness is quite reasonable and justified.

By the criterion of the "largeness of manifestations in various activities" general giftedness (expressed in a wide range of activities) and special giftedness (manifested in a narrower range-for example, only in mathematics) are distinguished. The question of the universal manifestation of general giftedness remains controversial. Teplov sharply criticized the view according to which general giftedness is a "tool for anything in the world" that provides success in any activity and promotes effective adaptation to any new conditions (Teplov, 1985). Basing his views on the opinions of Rubinstein (1989), Teplov believed that it is necessary to relate general giftedness to specific activities and to search "inside" special giftedness.

In modern psychology, general giftedness is often associated with metacognitive abilities that determine the dynamics and regulation of the process of thinking (Alexander, Carr, \& Schwanenflugel, 1995). The concept of metacognitive giftedness has also been discussed (Karpov \& Skityaeva, 2005).

By the criterion of "age development specifics" early and late manifestations of giftedness are distinguished. According to Leytes (2000), in some cases it is just an age phenomenon. Not all child prodigies become outstanding adults. Often a child with surprising early development loses this advantage with age. Delayed development is possible too when "dormant" brilliant abilities manifest in adults and even older people who engage in creative work professionally and gain fame.

By the criterion of "degree of giftedness development" actual and potential giftedness are distinguished. The abilities of actually gifted children are already at a level that can provide them with high achievements in a particular field of activity. The abilities of children with potential giftedness have not formed to the same degree, and their achievements can even be lower than the standard. According to Jung (1997), this "latent" giftedness is difficult to recognize, and attempts to do so, based on separate characteristics, often lead to serious mistakes. According to Efroimson (1998), it is necessary to distinguish potential, developed, and accomplished geniuses. He also points out that a large number of potential geniuses "extinguished" because they did not manage to develop their abilities, and among those who did many "extinguished" at the implementation stage.

By the criterion of "form of manifestation" explicit giftedness (obvious in its manifestations) and hidden giftedness (atypical, masked) are distinguished. The most gross mistakes are made in the process of identifying hidden giftedness. A contributing factor here is the so-called dyssynchrony of development, which is usual in many gifted children (Terrassier, 1985). Because traditional psychometric tests are not "sensitive" to potential and hidden giftedness, I have developed a special method-psychodiagnostic training (Babaeva, 1998). 


\section{The dynamic principle}

The dynamic principle reflects the role of process aspects in the phenomenon of giftedness. In many concepts of giftedness the approach that Vygotsky called static is typical. Proponents of this approach are interested mainly in the various parameters and appropriate methods of ability measurement, not in the "element of giftedness." In this regard, Vygotsky (1983) pointed out the need to create a new, dynamic theory of giftedness in the future. He formulated some basic principles for this future "dialectical doctrine of plus- and minus-giftedness." The core of this dynamic theory of giftedness, according to Vygotsky, should include three basic principles. When enunciating them, he relied on Lipps's (1907) "theory of the dam," Pavlov's (1951) concept of the "target reflex," and Adler's idea of overcompensation (1927).

The "social determination of development" principle states that a child's maladjustment to the social-cultural environment brings about the formation of barriers to positive psychological development.

The "prospect of the future" principle says that the emerging barriers stimulate "the switching on" of a compensation process; they become "purposeful points" of development and direct it.

The "compensation" principle states that the presence of a barrier strengthens and perfects psychological functions. This process can lead to the child's successfully overcoming psychological barriers and finally to the child's adjustment to the social-cultural environment. But there is a danger that compensation may go along the wrong path, causing the inadequate, delayed development of a child's mind.

The novelty of the dynamic theory of giftedness is not new methods for the quantitative measurement of giftedness or some new parameters for its evaluation. Its novelty consists in the refusal to believe that these measures are crucial. Barriers to the development of mental processes and even defects don't become a verdict for the child's development as a whole. Thus, a paradigm shift occurs: the transition from selection diagnostics to developmental diagnostics (Asmolov, 1996).

\section{Research project}

Based on the ideas of Vygotsky, I conducted a 10-year longitudinal study of Moscow schoolchildren who learned in three different schools (Babaeva, 1999, 2001). In Russia the selection of children for enrollment in programs for the gifted is often based on expert evaluation by teachers and on psychometric testing. The target group consisted of children who were evaluated as "nongifted" on the basis of these criteria ( 31 children aged 6-7 years; average IQ $=100.4$. measured with the Wechsler test). Four other classes were control groups. Two classes (C1 and C2) included gifted children attending the same school but being educated in special programs; two additional classes (C3 and C4) included "average" children from other schools running traditional programs. The number of students and the mean IQ for these classes were as follows: $\mathrm{C} 1: 30$ children, IQ $=123.3 ; \mathrm{C} 2: 28, \mathrm{IQ}=120.5$; C3: 36, IQ = 112.4; C4: 38, IQ = 103.2.

Special diagnostic and remedial work was carried out with the target group. Diagnostics included both traditional psychometric tests and original methods designed to identify barriers to the development of abilities. Their educational pro- 
gram was extended with developmental training and new educational courses (an integrative course and a psychology course).

This longitudinal study allowed us to verify the main points of the dynamic theory of giftedness and confirm the efficacy of our original diagnostic, developing and training methods based on this theory. The results revealed the high developmental potential of the children who were classified as nongifted on the basis of traditional selective methods. After 6 years of special education and of nurturing, these children (with a mean IQ of 128.9) became almost equal to the "gifted children" on intelligence and creativity measures, and they were far ahead of children in the "average" groups, who were educated in traditional programs.

This research confirmed the assumption that an increase in intelligence and creativity indexes is determined largely by the peculiarities of psychological coping mechanisms. Therefore, to continue research in this direction my colleagues and I conducted a study of gifted children's coping behavior (Babaeva, Briseva, Koltsova, 2013). It allowed us to analyze in detail the role of barriers to the development of giftedness and to evaluate children's ability to overcome these barriers.

\section{Suggestions for further research}

The dynamic approach may be useful for modernizing traditional psychometric tests. Often the diagnostics of giftedness focuses only on the productive side of the phenomenon, and important process aspects are ignored. This procedure can lead to serious errors in the identification of gifted children. In this regard, some attempts have been made to combine Vygotsky's ideas of the "zone of proximal development" with the psychometric paradigm; these attempts have led to the creation of methods of "dynamic testing" (Guthke \& Beckmann, 2003).

Consideration of the dynamic aspects of the testing procedure can also contribute to solving a number of controversial issues-for example, the various limitations in the testing procedure. According to Druzhinin (2007), tests of intelligence and creativity can be figuratively ranged on a scale from "regimentation" to "freedom." When regimentation is high, the number of tasks, the completion time, and so forth are rigidly fixed. It is assumed that these restrictions intensify intellectual activity, while creativity requires freedom. This view is challenged by a number of authors who believe that a time limit should not be set in the diagnostics of intelligence.

The question of the relationship between creativity and intelligence is controversial too. Thus, according to the theory of the intelligence "threshold," with IQ scores below 115-120 intelligence and creativity form a single factor, but when IQ is above 120, creativity becomes independent of the IQ index. Also, when IQ is above 180, this pattern is broken. Varying test conditions (time limits, instructions, etc.) lead to significant changes in the correlation of IQ with indicators of creativity (Sternberg, 1999).

Identification of the psychological mechanisms that underlie these results requires special methods and tools. Tikhomirov's scientific school claims that the structure of mental activity depends on the conditions of its occurrence and the specifics of the goals of the subject (Tikhomirov, 1969; Tikhomirov, Babaeva, Berezanskaya, Vasilyev, \& Voiskounsky, 1999). In our studies my colleagues and I 
used eye-tracking and pupillometry methods; the tasks from Raven's Progressive Matrices were performed by subjects in different time modes (Babaeva, Rotova, \& Sabadosh, 2012). Under time pressure significant reductions in hypothesizing, verbalization, refinement, and validation of hypotheses were detected, as well as in the process of selecting the final choice of several alternatives posed by the subject. In general, there was a narrowing of the orientation zone, finding the solution to the task was not extensive, and the feeling of uncertainty in regard to the correctness of the chosen decision increased. These data largely explain the changes of correlations between IQ and creativity measures when time limits for solving the task vary. They are consistent with the results of studies performed by Smirnov and Grigorenko (1988), according to which the number of hypotheses formulated by subjects solving intellectual tasks correlated with creativity level as measured by the Torrance Tests of Creative Thinking.

\section{The principle of the holistic analysis of the phenomenon of giftedness}

For a long time the level of intelligence development was considered to be the main indicator of giftedness. Many authors have noted that personality traits and specific social-cultural living conditions should also be taken into account in the giftedness diagnostics. Studies of the emotional and motivational aspects and the personality characteristics of outstanding people were carried out in the framework of the personal approach, which has become an alternative to the cognitive approach. However, in this case, the cognitive processes have eluded the attention of researchers. Many modern psychologists assume the importance of a holistic approach to the analysis of giftedness, noting the impossibility of a "break" between its cognitive and personal aspects and stressing that the indissoluble unity of the whole is dynamic and combines individual and social, intellectual, and emotional aspects (Babaeva \& Voiskounsky, 2003; Landau, 2002).

A number of basic research directions promote the cultural-activity approach in the psychology of giftedness. One of them is connected with Vygotsky's thesis about the "unity of intellect and affect" and with identification of the (both positive and negative) roles of emotions in the development and manifestation of giftedness. At the same time attention should be paid not only to "social" but also to "intellectual" emotions. According to my data, these components of the emotional sphere of gifted children develop unevenly and nonsimultaneously ( $\mathrm{Ba}$ baeva, 2008).

The "key" to the development and manifestation of skills lies in changing the motivation and the attitude of the subject toward his or her activity. Therefore it is necessary to investigate the processes of task acceptance and the formation of attitudes toward it. In this context one of the study cycles my colleagues and I have conducted is devoted to exploring the relationships between subjective creativity value, implicit ideas about it, and the connection between performance on creativity tests and the results of its subjective evaluation (Babaeva, Popova, \& Sabadosh, 2008; Babaeva \& Sabadosh, 2011).

Traditionally, in the activity-approach framework the semantic and incentive functions of motive are analyzed. The structuring function of motive was developed and empirically verified by Tikhomirov's scientific school (Babaeva et al., 
2009; Tikhomirov et al., 1999). These issues open up new perspectives for the study of the ontogenesis of giftedness and actual genesis, including the specifics of gifted children's "zone of proximal development."

Equally important is the study of co-creation, including an analysis of idea exchange. Among the psychological mechanisms that ensure the success of these processes, we have identified the following: cognitive enrichment, translation of "creative emotional background," and comparison of one's own options and creative products with similar partner's characteristics (Babaeva \& Yagolkovskiy, 2006).

Revealing the social-cultural aspects of giftedness is undeniably crucial to the implementation of the cultural-activity approach. These aspects concern not only the formulation of new problems but also the revision of previously collected data-for example, data on the U-shaped dependence of the creativity index on age: in primary school children creativity "slowdown" is often observed; it is explained largely by the negative influence of the traditional school system, and it is just temporary (Sternberg, 1999). According to many authors, one of the limitations to creativity is stereotypical thinking. I have identified qualitatively different forms of stereotypes: cognitive and social. In the first case an independent overcoming of the stereotype seems rather tough for a child; in the second case a "little dreamer" can voluntarily give up his or her original ideas in favor of creative products which are approved by the social environment and "match the format" in order to get a good grade or encouragement from adults (Babaeva, 2001).

\section{Conclusion}

Analysis of current trends in the study of giftedness suggests that the general psychological cultural-activity approach, based on the ideas of Vygotsky and Leontiev, as well as the theoretical and empirical developments of Tikhomirov's scientific school, is productive for solving many theoretical, empirical, and applied problems in this area. Analysis of the qualitative uniqueness of different aspects and manifestations of children's giftedness involves not only measuring their performance but also revealing the specifics of the underlying processes and the specific psychological mechanisms. A paradigm shift in the psychology of giftedness connected with the transition from the static to the holistic/dynamic approach also involves a transition to new psychopedagogical technologies for the identification, education, and development of gifted children.

\section{References}

Adler, A. (1927). The practice and theory of individual psychology. New York: Harcourt Brace.

Alexander, J. M., Carr, M., \& Schwanenflugel, P. J. (1995). Development of metacognition in gifted children: Directions for future research. Developmental Review, 15(1), 1-37. doi: 10.1006/drev.1995.1001

Asmolov, A. G. (1996). Kulturno-istoricheskaya psihologiya i konstruirovanie mirov [Cultural-historical psychology and the design of worlds]. Moscow: Institut Prakticheskoy Psikhologii; Voronezh: NPO MODEK. 
Babaeva, J. D. (1998). Psihologicheskiy trening dlya viyavleniya odarennosti [Psychological training for the identification of giftedness]. Moscow: Molodaya Gvardiya.

Babaeva, J. D. (1999). A dynamic approach to giftedness: Theory and practice. High Abilities Studies, 10(1), 51-68. doi: 10.1080/1359813990100105

Babaeva, J. D. (2001). Idei L. S. Vygotskogo o dinamicheskom podhode k odarennosti i perspectivy ikh razvitiya [L.S. Vygotsky's ideas about the dynamic approach to giftedness and perspectives on its development]. In I.A. Petuhova (Ed.) Kulturno-istoricheskaya Psihologiya Razvitiya:materialy pervyh chteniy, posvyashennyh pamyati L.S. Vygotskogo. [Culturalhistorical psychology of development: proceedings of the first readings in L.S. Vygotsky's memory]. (pp. 126-145). Moscow: Smysl.

Babaeva, J. D. (2008). Sovremennye tendencii v issledovanii odarennosti [Modern tendencies in giftedness studies]. Vestnik Moskovskogo Universiteta, ser. 14, Psikhologiya [Moscow University Psychology Bulletin], 2, 154-168.

Babaeva, J. D., Berezanskaya, N. B., Vasilyev, I. V., Voiskounsky, A. E., \& Kornilova, T. V. (2009). O vklade O. K. Tikhomirova v metodologiyu, teoriyu i experimentalnuyu praktiku psihologicheskoy nauki [The contribution of Oleg K. Tikhomirov to the methodology, theory, and experimental practice of psychology]. Methodology and History of Psychology, 4(4), $9-27$.

Babaeva, J. D., Briseva, Y., \& Koltsova, A. (2013). The specialties of coping behavior and the difficult life situations of Russian school students with different intelligence levels. Academic Journal of Interdisciplinary Studies, 2 (3), 489-506.

Babaeva, J. D., Popova, E. N., \& Sabadosh, P. A. (2008). Tvorcheskiye sposobnosti i tsennostnaya struktura lichnosti. [Creative values and a person's value system]. Psikhologiya i Shkola [Psychology and School], 1, 55-59.

Babaeva, J. D., Rotova, N. A., \& Sabadosh, P. A. (2012). Determinanty vypolneniya testa intellekta $\mathrm{v}$ usloviyah ogranicheniya vremeni [Determinants of intellectual test performance under time pressure]. Psihologicheskiye Issledovaniya [Psychological Studies], 5(25), 4. Retrieved from http://psystudy.ru/index.php/eng/2012v5n25e/745-babaeva25e.html

Babaeva, J. D., \& Sabadosh, P. A. (2011). Akademicheskaya odarennost i tsennosti podrostkov [Academic giftedness and adolescents' values]. In L. I. Larionova (Ed.), Psyhologo-pedagogicheskiye problemy odarennosti: Teoriya i praktika: Proceedings of VII international conference (Vol. 2, pp. 10-17). Irkutsk: Irkutskii gosudarstvennyi tekhnicheskiy universitet (Irkutsk state technical university).

Babaeva, J. D., \& Varvaricheva, Y. I. (2011, July). Types, causes and functions of creative crises. Paper presented at the 12th European Congress of Psychology, Istanbul, p. 324.

Babaeva, J. D., \& Voiskounsky, A. E. (2003). Odarennyi rebenok za komputerom [The gifted child at a computer]. Moscow: Skanrus.

Babaeva, J. D., \& Yagolkovskiy, S. R. (2006). Dinamika proyavleniy kreativnosti v usloviyah obmena ideyami [Manifestations of the dynamics of creativity in the process of idea exchange]. In B. S. Bratus \& E. E. Sokolova (Eds.), Uchenye zapiski kafedry obschey psikhologii, 2, 317-337.

Bogoyavlenskaya, D.B., Shadrikov V.D., Babaeva J.D., Kholodnaya M.A. et al. (2003). Rabochaya konceptsiya odarennosti [An operational conception of giftedness]. Moscow: MO RF.

Druzhinin, V. N. (2007). Psikhologiya obschih sposobnostey [Psychology of general abilities]. (3rd ed.). St. Petersburg: Piter.

Efroimson, V. P. (1998). Genialnost i genetica [Exceptional intellectual ability and genetics]. Moscow: Russkiy Mir.

Freeman, J. (1995). Recent Studies of Giftedness in Children. Journal of Child Psychology and Psychiatry, 36: 531-547. doi: 10.1111/j.1469-7610.1995.tb02313.x 
Guilford, J. P., \& Christensen, P. R. (1973). The one-way relation between creative potential and IQ. Journal of Creative Behavior, 7(4), 247-252. doi: 10.1002/j.2162-6057.1973.tb01096.x

Guthke, J., \& Beckmann, J. F. (2003). Dynamic assessment with diagnostic programs. In R. J. Sternberg, J. Lautrey, \& T. I. Lubart (Eds.), Models of intelligence: International perspectives. Washington, DC: American Psychological Association.

Heller, K. A. (1997) Diagnostika i razvitie odarennyh detey i podrostkov [Diagnostics and development of gifted children and youth]. In D. B. Bogoyavlenskaya (Ed.), Osnovnye sovremennye koncepcii tvorchestva $i$ odarennosti [The main contemporary concepts of creativity and giftedness], pp. 243-264. Moscow: Molodaya Gvardiya.

Jung, K. G. (1997). Fenomen odarennosti [The giftedness phenomenon]. In Konflikty detskoy dushi [Conflicts of a child's soul] (pp. 151-164). Moscow: Kanon.

Karpov, A. V., \& Skityaeva, I. M. (2005). Psikhologiya metacognitivnykh protsessov lichnosti [The psychology of a person's metacognitive processes]. Moscow: IP RAN.

Landau, E. (2002) Odarennost trebuet muzhestva [The courage to be gifted]. Moscow: Academia.

Leytes, N. S. (2000) Vozrastnaya odarennost shkolnikov [The growth of giftedness in schoolchildren]. Moscow: Academia.

Lipps, T. (1907) Rukovodstvo k psikhologii. [Manual on psychology]. St. Petersburg: O. N. Popova.

Marland, S. P., Jr. (1972). Education of the gifted and talented: Report to the Congress of the United States by the U.S. Commissioner of Education and background papers submitted to the U.S. Office of Education (2 vols.). Washington, DC: U.S. Government Printing Office.

Pavlov, I. P. (1951) Dvadtsatiletniy opyt objectivnogo izucheniya vysshey nervnoy deyatelnosti (povedeniya) jivotnyh. [The twenty-year experience of the objective study of the highest nervous activity (animal behavior)]. In I. P. Pavlov, Collected works (Vol. 3). Moscow/Leningrad: AN USSR.

Renzulli, J. S. (1978). What makes giftedness? Reexamining a definition. Phi Delta Kappan, 60, $180-184$.

Renzulli, J. S. (1986) The three-ring conception of giftedness: A developmental model for creative productivity. In R. J. Sternberg \& J. E. Davidson (Eds.), Conceptions of giftedness (pp. 332-357). New York: Cambridge University Press.

Renzulli, J. S., Reis, S. M., \& Smith, L. H. (1981). The revolving door identification model. Mansfield Center, CT: Creative Learning Press.

Rubinstein, S. L. (1989) Osnovy obshey psikhologii [The foundations of general psychology]. (3rd ed.). Moscow: Pedagogika.

Runco, M. A., \& Albert, R. S. (1986). The threshold hypothesis regarding creativity and intelligence: An empirical test with gifted and non-gifted children. Creative Child Quarterly, 11, 212-218.

Smirnov, S. D., \& Grigorenko, E. L. (1988). Issledovaniye processa vydvizheniya i proverki gipotez pri reshenii zadach s neopredelennymi usloviyami [An investigation of the process of hypothesizing and testing for solving problems under uncertain conditions]. Vestnik Moskovskogo Universiteta, ser. 14, Psikhologiya [Moscow University Psychology Bulletin], 1, 61-68.

Sternberg, R. J. (Ed.). (1999). Handbook of creativity. New York: Cambridge University Press.

Teplov, B. M. (1985). Sposobnosti i odarennost [Abilities and giftedness]. In B. M. Teplov, Izbranniye trudy [Selected works], Vol. 1, pp. 15-41. Moscow: Pedagogika.

Terrassier, J.-C. (1985). Dyssynchrony-uneven development. In J. Freeman (Ed.), The psychology of gifted children (pp. 265-274). Chichester, UK: Wiley. 
Tikhomirov, O. K. (1969). Struktura myslitelnoy deyatelnosti cheloveka (opyt teoreticheskogo i experimentalnogo issledovaniya) [The structure of human mental activity (a theoretical and empirical study)]. Moscow University Press.

Tikhomirov, O. K., Babaeva, J. D., Berezanskaya, N. B., Vasilev, I. A., \& Voiskounsky, A. E. (1999). Razvitiye deyatelnostnogo podhoda v psikhologii myshleniya [The development of the activity approach in the psychology of thinking]. In A. E. Voiskounsky, A. N. Zhdan, \& O. K. Tikhomirov (Eds.), Traditsii i perspektivy deyatelnostnogo podkhoda v psikhologii. Shkola A. N. Leontiyeva [Traditions and perspectives of the activity approach in psychology. A. N. Leontiev's school] (191-234). Moscow: Smysl.

Vygotsky, L. S. (1983). Osnovy defectologii [The foundations of defectology]. In L. S. Vygotsky, Collected works, Vol. 5. Moscow: Pedagogika.

Received: 01 September 2013 Accepted: 16 October 2013 Available online: 15 December 2013 